\title{
LIFE QUALITY ASSESSMENT IN THE CITY OF JELGAVA
}

\author{
Liga Feldmane ${ }^{1}$ Mg.geogr. \\ ${ }^{1}$ University of Latvia
}

\begin{abstract}
Studies about life quality and people's satisfaction with life currently are focused on cities as important cultural, social and political centres. The aim of the study is to evaluate residents' satisfaction with life quality in Jelgava; and to achieve it, such methods as analysis of theoretical literature and statistical analysis, classification and comparison of data about satisfaction with life quality in Jelgava city from survey "Quality of Life in Cities", which was conducted by Central Statistical Bureau of Latvia in 2017, were applied. Results demonstrate that overall satisfaction level with living in Jelgava is relatively high and is one of the highest among other regional cities of Latvia. It was observed that satisfaction with living in Jelgava is closely related with several indicators that characterized the household's living standard and financial situation - the worse was situation in the household, the lower satisfaction level with life in Jelgava was. The residents of Jelgava are mainly satisfied with environmental factors, while such elements as the condition of the streets and buildings, health care services and public transport were assessed the lowest. The main issues facing Jelgava were road infrastructure, unemployment and health services, while noise level, education and training as well as air pollution were the least mentioned. It was observed that people firstly point out issues that are common with their subjective experience and what bother their individual life.
\end{abstract}

Key words: life satisfaction, life quality, life in a city, elements affecting quality of life.

JEL code: P25; P46; R20

\section{Introduction}

The concept of life quality is widely studied in interdisciplinary science fields and currently, especially in European countries (Okulicz-Kozaryn, Valente, 2018; Weziak-Bialowolska, 2016; Rosu et al., 2015; Shaker, 2015; Sorensen, 2014), it focuses on cities as the centres of social, economic and political life as well as residence for major part of people. As Zenker et al. (Zenker et al, 2013) has argued a satisfied resident is the most important aim of cities' management, because citizens are active partners and co-producers of public goods, services and policies. In other words - satisfied human capital builds better economy; therefore it is important for city's economists and leaders to observe the satisfaction level with life quality in it, since results allow to predict future changes in city's economy, social processes and development.

According to theoretical studies (Turksever, Atalik, 2001; Ballas, 2013), life quality can be measured both with objective and subjective indicators. In the beginning of $21^{\text {st }}$ century, objective indicators (for example, natural environment, income, consumption, wages and rents, local amenities, environmental pollution), which are relatively easy to quantify and collect, were most often analysed, but in recent years there is a rapidly growing number of interdisciplinary studies in which subjective measurements are studied (for example, Ballas, Tranmer, 2012; Switek, 2016; Bartram, 2013). The most often used concepts are happiness, subjective well-being and satisfaction with life and living environment, which were adapted from the field of psychology to other scientific fields. According to Pittau et al. (2010), life satisfaction is closer to the concept of an overall and more stable living flourishing and actualizing the best potential within oneself, while happiness is more volatile concept of current emotional state.

Following current trends in science, also in this study subjective satisfaction is analysed and the aim of this study is to evaluate residents' satisfaction with life quality in Jelgava, which is the fourth largest city of Latvia; and life satisfaction in Jelgava is defined as research object. In order to achieve the aim, following tasks have been set: 1 ) to find out how satisfied inhabitants of Jelgava are with living in the city and its facilities; 2) to identify the main issues in the city according to 
respondents; 3) to analyse if there are differences among various respondent groups in their satisfaction level with living in Jelgava.

In order to assess how satisfied the residents of Jelgava are with life quality in the city, data from survey "Quality of Life in Cities" were analysed, which was conducted by Central Statistical Bureau of Latvia in 2017 when approximately 500 respondents from each 8 regional level cities of Latvia - Daugavpils, Jekabpils, Jelgava, Jurmala, Liepaja, Rezekne, Valmiera, Ventspils - were asked to answer several questions about satisfaction with life in their city. In this paper 501 Jelgava respondents' answers with statistical methods were analysed about overall satisfaction with living in the city, their satisfaction with infrastructure and facilities of the city as well as the main issues of Jelgava. Respondents' answers were analysed considering their features such as age, household description, financial situation of household and duration in the city; comparison with other cities of Latvia was carried out.

The following research methods were used in the study:

1) analysis of theoretical literature about previous studies of life quality and residents' satisfaction with life in the cities;

2) statistical analysis, classification and comparison of data about satisfaction with life quality in Jelgava city from survey "Quality of Life in Cities", which was conducted by Central Statistical Bureau of Latvia in 2017.

\section{Research results and discussion}

Results of survey demonstrate that overall satisfaction level with living in Jelgava is relatively high because $95.2 \%$ of all respondents answered that they were very satisfied or rather satisfied with life in the city. In comparison with the other largest cities of Latvia (Fig. 1), it is the second highest satisfaction level after Valmiera where $98 \%$ of respondents were satisfied. It should be mentioned that also in European context such result is high because among the 83 cities included in the survey, which was conducted in 2015 (European Commission, 2016), only in 23 cities the level of satisfaction exceeded $95 \%$, and similar results as in Jelgava were observed in such wellknown and developed cities as Glasgow (UK), Newcastle (UK), Burgas (BG), Luxemburg (LU), Graz (AT) and Wien (AT), while in the capital Riga satisfaction level was $89 \%$ high.

According to previous studies, satisfaction with life and life quality is influenced by person's age or position in life course (Qu, De Vaus, 2015; Plagnol, 2010; Mehlsen et al., 2003) as well as with living conditions, and most often with financial situation of the household (Cheung, Lucas, 2014; Gray, 2014). Qu and De Vaus (2015) argue that life satisfaction declines from the age of 15 through to the mid-30s and is at its lowest between the mid-30s to the early 50s. Also Plagnon (2010) agrees with them and points out that subjective satisfaction is U-shaped: happiness is highest when people are young and old. He also adds that such life events and transitions as family formation, family dissolution, employment and health have an impact on people's evaluations of their subjective well-being. The results of Gray's study (2014) approve that the subjective financial position of the household is to be an important determinant of overall life satisfaction, mediating the effects between the monetary financial position of the household and overall life satisfaction. Also Cheung and Lucas (2014) found positive correlation between life satisfaction and income, education, subjective health, domain satisfaction, and happiness. 


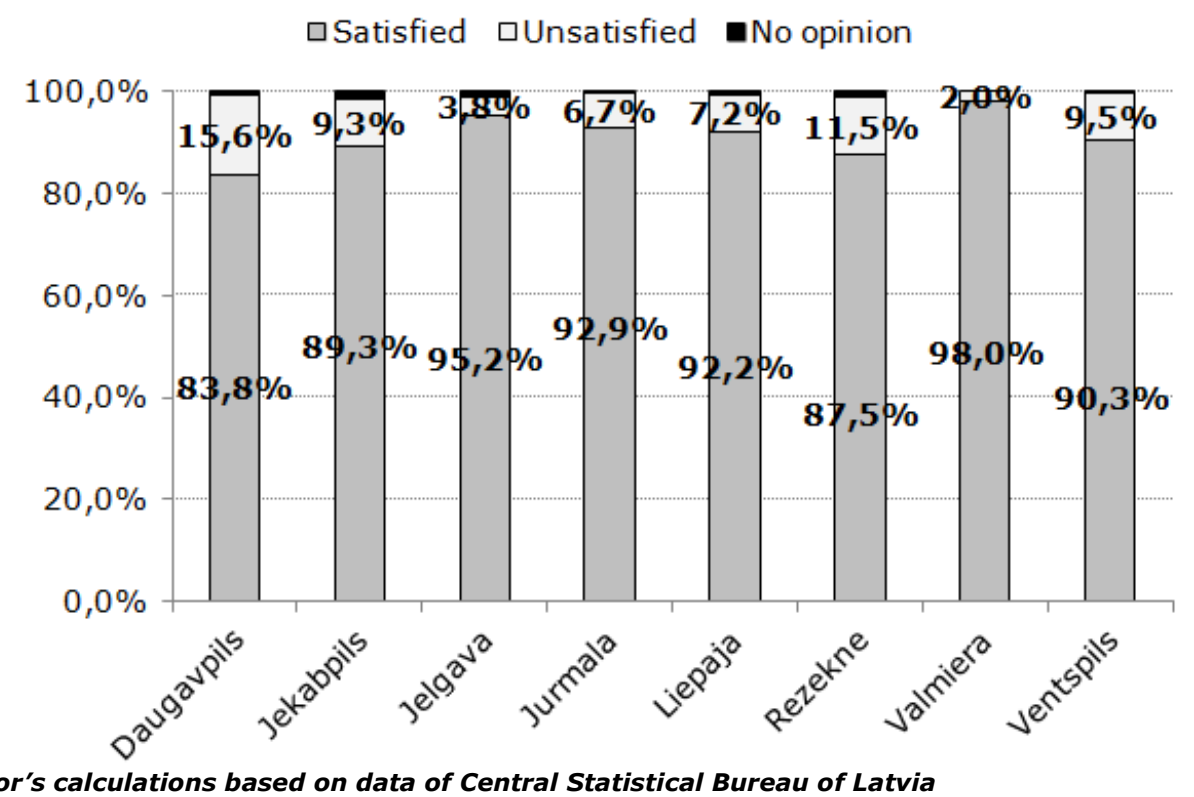

Source: author's calculations based on data of Central Statistical Bureau of Latvia

Fig. 1. Respondents overall satisfaction level with living in their city, \% of all respondents

As shown in Table 1, differences were found also in this study among different respondent groups and their satisfaction level. For instance, young people were considerably less satisfied with living in Jelgava than people above 30 and 65. Although it was observed that respondent's educational level have influenced satisfaction - the higher was educational level of respondents the more satisfied they were with the life in Jelgava - however this correlation was found only up to secondary educational level while opinion of people with higher education became slightly more critical. Correlation was discovered also among several indicators that characterized the household's living standard and financial situation - the worse was situation in the household the lower was satisfaction level with life in Jelgava. For example, among unemployed respondents and students as well as those who evaluated their financial situation as unsatisfactory were less satisfied persons than among employed and financially satisfied respondents. In addition, household's description and number of persons in household, what also could be linked with person's overall happiness and financial situation, approved that the more persons shared one dwelling, the less were income per capita as a result also satisfaction level with life and living in the city was lower.

According to Ballas and Tranmer (Ballas, Tranmer, 2012), in survey what was conducted in Great Britain respondents who had lived in household for more than 5 years reported their overall well-being higher than those who had lived there less than a year. It was explained with possibility that person may feel better about themselves when they have lived at current address for a relatively long period and usually have developed local social networks in their neighbourhood therefore perhaps they feel also more financially stable. In the case of Jelgava, results are similar to above mentioned survey in Great Britain regarding those who have lived relatively short period the least satisfied were respondents who lived in Jelgava less than 5 years, while the most satisfied were persons who lived in the city $5-10$ years and who were born there. However, in Jelgava also respondents who lived more than 10 years were less satisfied with living in the city than those who lived there 5 - 10 years, which can be linked with previous studies (Switek, 2016; Bartram, 2013) where it was discovered that migration event significantly increased satisfaction with life compared 
with situation before move, but it did not last more than 6 years and usually returned in previous level.

Overall satisfaction with living in Jelgava city, \%

Table 1

\begin{tabular}{|c|c|c|c|c|c|}
\hline & & $\begin{array}{c}\text { Number of } \\
\text { respondents }(n)\end{array}$ & Satisfied & Unsatisfied & No opinion \\
\hline \multirow{3}{*}{ Age } & $14-29$ & 51 & $88 \%$ & $10 \%$ & $2 \%$ \\
\hline & $30-64$ & 346 & $96 \%$ & $3 \%$ & $1 \%$ \\
\hline & $65+$ & 104 & $97 \%$ & $2 \%$ & $1 \%$ \\
\hline \multirow{5}{*}{ Education } & Higher education & 185 & $95 \%$ & $4 \%$ & $1 \%$ \\
\hline & $\begin{array}{l}\text { Academic secondary } \\
\text { education/ vocational } \\
\text { secondary education }\end{array}$ & 266 & $97 \%$ & $2 \%$ & $1 \%$ \\
\hline & Basic education & 45 & $91 \%$ & $9 \%$ & $0 \%$ \\
\hline & Primary education & 4 & $50 \%$ & $50 \%$ & $0 \%$ \\
\hline & No education & 1 & $100 \%$ & $0 \%$ & $0 \%$ \\
\hline \multirow{5}{*}{$\begin{array}{l}\text { Household } \\
\text { description }\end{array}$} & Single person & 84 & $96 \%$ & $2 \%$ & $1 \%$ \\
\hline & Married without children & 105 & $95 \%$ & $4 \%$ & $1 \%$ \\
\hline & Single parent & 10 & $90 \%$ & $10 \%$ & $0 \%$ \\
\hline & Married with children & 157 & $97 \%$ & $3 \%$ & $0 \%$ \\
\hline & Other & 145 & $92 \%$ & $6 \%$ & $2 \%$ \\
\hline \multirow{4}{*}{$\begin{array}{l}\text { Respondent } \\
\text { occupation }\end{array}$} & Workers & 304 & $96 \%$ & $3 \%$ & $1 \%$ \\
\hline & Not working & 80 & $90 \%$ & $8 \%$ & $3 \%$ \\
\hline & Student & 14 & $86 \%$ & $14 \%$ & $0 \%$ \\
\hline & Retired person & 103 & $97 \%$ & $2 \%$ & $1 \%$ \\
\hline \multirow{5}{*}{$\begin{array}{l}\text { Lives in the } \\
\text { city for... }\end{array}$} & No answer & 1 & $100 \%$ & $0 \%$ & $0 \%$ \\
\hline & Was born there & 219 & $96 \%$ & $3 \%$ & $0 \%$ \\
\hline & More than 10 years & 222 & $94 \%$ & $5 \%$ & $1 \%$ \\
\hline & 5-10 years & 30 & $100 \%$ & $0 \%$ & $0 \%$ \\
\hline & Less than 5 years & 29 & $93 \%$ & $3 \%$ & $3 \%$ \\
\hline \multirow{5}{*}{$\begin{array}{l}\text { Household } \\
\text { composition: } \\
\text { number of } \\
\text { persons }\end{array}$} & 1 & 85 & $96 \%$ & $2 \%$ & $1 \%$ \\
\hline & 2 & 134 & $96 \%$ & $4 \%$ & $1 \%$ \\
\hline & 3 & 114 & $96 \%$ & $4 \%$ & $1 \%$ \\
\hline & 4 & 88 & $95 \%$ & $3 \%$ & $1 \%$ \\
\hline & $5+$ & 80 & $93 \%$ & $6 \%$ & $1 \%$ \\
\hline \multirow{3}{*}{$\begin{array}{l}\text { Financial } \\
\text { situation of } \\
\text { household }\end{array}$} & Satisfied & 293 & $99 \%$ & $1 \%$ & $0 \%$ \\
\hline & Unsatisfied & 199 & $91 \%$ & $8 \%$ & $1 \%$ \\
\hline & No answer & 9 & $78 \%$ & $0 \%$ & $22 \%$ \\
\hline
\end{tabular}

Source: author's calculations based on data of Central Statistical Bureau of Latvia

Overall satisfaction with life in the city is influenced by several elements affecting quality of life, which individual meets in daily life; therefore, in survey respondents were asked to evaluate how satisfied they were with cleanliness, the noise level, the quality of the air, educational facilities, availability of retail shops, green space, public spaces, the state of the streets and buildings, cultural facilities, sports facilities, health care services and public transport. As shown in Figure 2, residents of Jelgava were the most satisfied with availability of retail shops and green spaces, following cleanliness, air quality and the noise level, instead the lowest satisfaction level was with the state of streets and buildings, public transport and health care services. Results illustrate that 
people were mainly satisfied with environmental factors, which means that Jelgava provides good, environmentally friendly living residence, while public services are in worse situation and should be improved.

\section{口Very satisfied aRather satisfied aRather unsatisfied aNot at all satisfied aNot opinion}

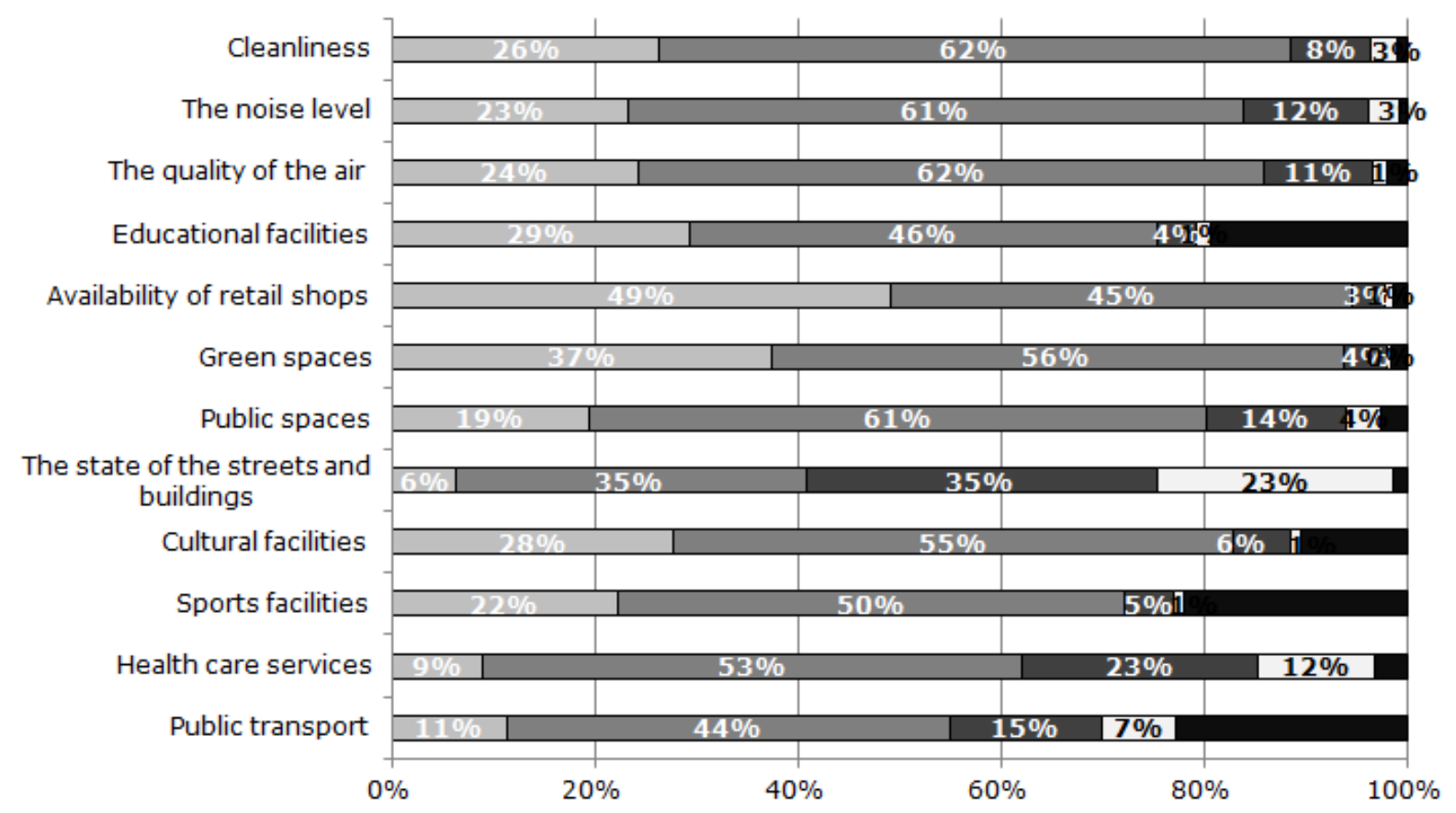

Source: author's calculations based on data of Central Statistical Bureau of Latvia

Fig. 2. Satisfaction with infrastructure, facilities and environment of Jelgava city, \%

In comparison with the other biggest cities of Latvia, in Jelgava was the lowest satisfaction level with public transport, which was the same as in Valmiera - only $55 \%$ of respondents were satisfied with it, while in Daugavpils it reached $85 \%$. In Jelgava, there was observed also second lowest satisfaction level with the state of the streets and building after Jekabpils where satisfaction level was even lower and reached only $36 \%$. Although satisfaction with healthcare services in Jelgava was only $62 \%$, compared with other cities it was the second highest result after Jurmala where $64 \%$ of respondents were satisfied with this facility, while in Daugavpils and Rezekne satisfaction level was as low as $45 \%$ and $46 \%$. Jelgava stood out in comparison with other cities also with educational facilities: there were $75 \%$ satisfied respondents in the city which was the second highest result after Valmiera ( $81 \%$ satisfied) while in the other cities satisfaction was lower. While satisfaction with environmental factors in Jelgava was high, also results in the other cities showed that respondents were mainly satisfied with air quality, noise level and cleanliness and only residents of Ventspils evaluated air quality (47\% satisfied) and noise level (78\% satisfied) relatively lower.

Although overall satisfaction with living in the Jelgava was relatively high, though also there were some issues which influence life quality in the city. In survey, respondents were asked to mention three the most important issues in Jelgava, and results illustrate (Table 2) that the main issue detected was road infrastructure, which had been mentioned by $62 \%$ of respondents; and this issue was more important for residents who lived in the city for 5 - 10 years, those who were born there and young and financially satisfied persons who likely were the owners of private vehicles and could evaluate the road infrastructure better. In comparison, road infrastructure in 
other cities was mentioned slightly less often, from $6 \%$ in Ventspils up to $59 \%$ in Jekabpils. While on average unemployment was the most often mentioned issue in the other cities, in Jelgava it was only in the second place and $52 \%$ of respondents had pointed it out. Among them, more often were those respondents who lived in the city relatively shorter time, young people and people who were not satisfied with households' financial situation. Health care was the third most often mentioned issue as almost every second respondent had mentioned it, and it was a topical problem for older persons over 65 and financially unsatisfied individuals. Other issues such as social services, public transport, housing and safety were mentioned relatively less often, while noise, education and training and air pollution worried only $6-7 \%$ of respondents.

The most important issues in Jelgava according to respondents, \%

Table 2 of respondents who have mentioned the issue

\begin{tabular}{|c|c|c|c|c|c|c|c|c|c|c|}
\hline \multirow[b]{2}{*}{ Issue } & \multirow{2}{*}{$\begin{array}{l}\text { \% of all } \\
\text { respondents } \\
\text { mentioned } \\
\text { the issue }\end{array}$} & \multicolumn{4}{|c|}{ Lives in the city for... } & \multicolumn{3}{|c|}{ Age } & \multicolumn{2}{|c|}{$\begin{array}{c}\text { Financial situation of } \\
\text { household }\end{array}$} \\
\hline & & $\begin{array}{l}\text { Was } \\
\text { born } \\
\text { there }\end{array}$ & $\begin{array}{c}\text { More } \\
\text { than } \\
10 \\
\text { years }\end{array}$ & $\begin{array}{l}5-10 \\
\text { years }\end{array}$ & $\begin{array}{c}\text { Less } \\
\text { than } \\
5 \\
\text { years }\end{array}$ & $\begin{array}{l}14- \\
29\end{array}$ & $\begin{array}{l}30- \\
64\end{array}$ & $65+$ & Satisfied & Unsatisfied \\
\hline $\begin{array}{l}\text { Road } \\
\text { infrastructure }\end{array}$ & $62 \%$ & $66 \%$ & $59 \%$ & $67 \%$ & $55 \%$ & $71 \%$ & $65 \%$ & $47 \%$ & $69 \%$ & $53 \%$ \\
\hline Unemployment & $52 \%$ & $58 \%$ & $46 \%$ & $43 \%$ & $72 \%$ & $63 \%$ & $56 \%$ & $36 \%$ & $48 \%$ & $60 \%$ \\
\hline $\begin{array}{l}\text { Health } \\
\text { services }\end{array}$ & $48 \%$ & $50 \%$ & $47 \%$ & $43 \%$ & $48 \%$ & $35 \%$ & $47 \%$ & $56 \%$ & $45 \%$ & $53 \%$ \\
\hline Social services & $24 \%$ & $22 \%$ & $27 \%$ & $20 \%$ & $14 \%$ & $18 \%$ & $20 \%$ & $41 \%$ & $16 \%$ & $37 \%$ \\
\hline $\begin{array}{l}\text { Public } \\
\text { transport }\end{array}$ & $16 \%$ & $16 \%$ & $16 \%$ & $27 \%$ & $17 \%$ & $20 \%$ & $17 \%$ & $12 \%$ & $13 \%$ & $22 \%$ \\
\hline Housing & $14 \%$ & $16 \%$ & $12 \%$ & $17 \%$ & $7 \%$ & $16 \%$ & $15 \%$ & $9 \%$ & $12 \%$ & $16 \%$ \\
\hline Safety & $14 \%$ & $16 \%$ & $13 \%$ & $10 \%$ & $3 \%$ & $14 \%$ & $13 \%$ & $14 \%$ & $15 \%$ & $11 \%$ \\
\hline Noise & $7 \%$ & $5 \%$ & $11 \%$ & $0 \%$ & $7 \%$ & $6 \%$ & $8 \%$ & $8 \%$ & $6 \%$ & $10 \%$ \\
\hline $\begin{array}{l}\text { Education and } \\
\text { training }\end{array}$ & $7 \%$ & $6 \%$ & $4 \%$ & $20 \%$ & $14 \%$ & $12 \%$ & $8 \%$ & $1 \%$ & $8 \%$ & $6 \%$ \\
\hline Air pollution & $6 \%$ & $3 \%$ & $9 \%$ & $7 \%$ & $3 \%$ & $2 \%$ & $6 \%$ & $8 \%$ & $7 \%$ & $5 \%$ \\
\hline $\begin{array}{l}\text { Number of } \\
\text { respondents } \\
\text { (n) }\end{array}$ & 501 & 219 & 222 & 30 & 29 & 51 & 346 & 104 & 293 & 199 \\
\hline
\end{tabular}

Source: author's calculations based on data of Central Statistical Bureau of Latvia

A comparison of respondents' answers related to financial situation of household indicates that persons who were not financially satisfied more often than financially satisfied respondents had mentioned issues connected with persons' social well-being, for instance unemployment, health services, social services, housing; while financially satisfied persons had more often pointed out road infrastructure, safety, education and training as well as air pollution. Also, respondents' age influenced persons' opinion about most common issues, and while young people more often than the rest age groups had mentioned problems that were important for them, such as road infrastructure, unemployment, public transport, housing and education, people after 65 , in turn, more often had pointed out health services and social services. At last correlation was found also among respondent groups with different duration in the city: persons who had relocated their residence relatively recently were more worried about unemployment compared to other groups; those who lived in Jelgava 5 - 10 years more often than others had mentioned public transport, housing and education (most likely these were young families with children whom preschool 
education was topical issue); respondents who had born in the city were worried about road infrastructure, unemployment and health services.

Above mentioned results illustrate that people firstly point out issues that are common with their subjective experience and what bother their individual life; thereby personal experience, wellbeing and satisfaction have a great impact on overall satisfaction with living environment.

\section{Conclusions, proposals, recommendations}

1) Overall satisfaction level with living in Jelgava is relatively high $-95.2 \%$ of all respondents were satisfied with life in the city. This satisfaction level was the second highest among other regional cities of Latvia and was on the same level as it was observed in such well-developed cities as Wien and Graz in Austria or Glasgow and Newcastle in the United Kingdom.

2) Satisfaction with living in Jelgava was closely related with several indicators that characterized the household's living standard and financial situation - the worse was situation in the household the lower was satisfaction level with life in Jelgava.

3) The residents of Jelgava were mainly satisfied with environmental factors, which means that the city provides good, environmental friendly living residence while such indicators as the state of the streets and buildings, health care services and public transport were assessed the lowest. In comparison with other regional cities of Latvia, in Jelgava there was the lowest satisfaction level with public transport and second lowest satisfaction level with the state of the streets and building, while satisfaction with healthcare services and educational facilities was higher than in other cities.

4) The main issues facing Jelgava were road infrastructure, unemployment and health services, while noise level, education and training as well as air pollution were the least often mentioned. It was observed that people firstly pointed out issues that were common with their subjective experience and that bothered their individual life; thereby personal experience, well-being and satisfaction had a great impact on overall satisfaction with living environment.

5) The results show that Jelgava has high potential to retain current residents and to attract new ones. However city administration should continue to promote economic sustainability and to improve conditions for creation of new job opportunities, as a result financial situation of households could improve and therefore also overall satisfaction with life in the city would increase. Furthermore, as the road infrastructure was mentioned as main and outstanding issue in Jelgava, city administration should seek solutions for faster improvement of road and street conditions, especially in outskirts of Jelgava.

\section{Bibliography}

1. Ballas, D., Tranmer, M. (2012). Happy People or Happy Places? A Multilevel Modelling Approach to the Analysis of Happiness and Well-Being. International Regional Science Review, 35(I), p. 70-102.

2. Ballas, D. (2013). What Makes a "Happy City"? Cities, volume 32, p. 539-550.

3. Bartram., D. (2013). Happiness and 'Economic Migration': A Comparison of Eastern European Migrants and Stayers. Migration Studies, Volume 1, Issue 2, 1 July 2013, p. 156-175.

4. Cheung, F., Lucas, R. E. (2014). Assessing the Validity of Single-item Life Satisfaction Measures: Results from Three Large Samples. Quality of Life Research, v. 23, n. 10, p. 2809-2818.

5. European Commission. (2016). Quality of Life in European Cities 2015. Flash Eurobarometer 419. Retrieved: http://ec.europa.eu/commfrontoffice/publicopinion/index.cfm/Survey/getSurveyDetail/yearFrom/1974/year To/2016/surveyKy/2070. Access: 15.12.2017.

6. Gray, D. (2014). Financial Concerns and Overall Life Satisfaction: A Joint Modelling Approach. Sheffield Economic Research Papier Series, p. 1-32. 
7. Kaklauskas, A., Zavadskas, E.K., Radzeviciene, A., Ubarte, I., Podviezko, A., Podvezko, V., Kuzminske, A., Banaitis, A., Binkyte, A., Bucinskas, V. (2018). Quality of City Life Multiple Criteria Analysis. Cities. Volume 72, p. 82-93.

8. Mehlsen, M., Platz, M., Fromholt, P. (2003). Life Satisfaction Across the Life Course: Evaluations of the Most and Least Satisfying Decades of Life. International Journal of Aging \& Human Development. 57(3): p. 217-36.

9. Okulicz-Kozaryn, A., Valente, R.R. (2018). Livability and Subjective Well-Being Across European Cities. Applied Research in Quality of Life, p. 1-24.

10. Pittau, M.G., Zelli, R., Gelman, A. (2010). Economic Disparities and Life Satisfaction in European Regions. Springer. Social Indicators Research, 96, 339-361.

11. Plagnol, A. (2010). Subjective Well-being Over the Life Course: Conceptualizations and Evaluations. Social Research: an international quarterly of the social sciences, 77(2), pp. 749-768.

12. Rosu, L., Corodescu, E., Blageanu, A. (2015). Does Geographical Location Matter? Assessing Spatial Patterns in Perceived Quality of Life in European Cities. European Journal of Geography, Volume 6, Issue 2, p. 15-34.

13. Shaker, R.R. (2015). The Well-being of Nations: An Empirical Assessment of Sustainable Urbanization for Europe. International Journal of Sustainable Development and World Ecology, Volume 22, Issue 5, p. 375387.

14. Sorensen, J.F.L. (2014). Rural-Urban Differences in Life Satisfaction: Evidence from the European Union. Regional Studies, Volume 48, Issue 9, p. 1451-1466.

15. Switek, M. (2016). Internal Migration and Life Satisfaction: Well-Being Paths of Young Adult Migrants. Social Indicators Research, 125, p. 191-241.

16. Qu, L., De Vaus, D. (2015). Life Satisfaction Across Life Course Transitions. Australian Family Trends, No. 8. Retrieved: https://aifs.gov.au/publications/life-satisfaction-across-life-course-transitions. Access: 05.01.2018.

17. Turksever, A. N. E., \& Atalik, G. (2001). Possibilities and Limitations for the Measurement of the Quality of Life in Urban Areas. Social Indicators Research, 53(2), p. 163-187.

18. Weziak-Bialowolska D. (2016). Quality of Life in Cities - Empirical Evidence in Comparative European Perspective. Cities 58, p. 87-96.

19. Zenker, S., Petersen, S., \& Aholt, A. (2013). The citizen satisfaction index (CSI): Evidencefor a four basic factor model in a German sample. Cities, 31, 156-164. 